\title{
AIベースBGAはんだボール接合部の疲労寿命評価
}

\author{
石川 浩嗣*, 于 強**, 白鳥 正樹**
}

\section{Fatigue Life Evaluation of Al-Base BGA Solder Ball Joints}

\author{
Kouji ISHIKAWA* , Qiang YU** and Masaki SHIRATORI**
}

*日本発条株式会社研究開発本部（テ236-0004 神奈川県横浜市金沢区福浦3-10）

**横浜国立大学工学部（テ240-8501 神奈川県横浜市保土ヶ谷区常盤台79-5）

* Research \& Development Department, NHK Spring Co., Ltd. (3-10 Fukuura, Kanazawa-ku, Yokohama-shi, Kanagawa 236-0004)

**Department of Mechanical Engineering and Materials Science, Yokohama National University (79-5 Tokiwadai, Hodogaya-ku, Yokohama-shi, Kanagawa 240-8501)

\section{Abstract}

Al-Base BGA shows large bending behavior under thermal cycling. Therefore, it is important to evaluate the fatigue life of Al-Base BGA solder ball joints. The thermal cycle tests were carried out to confirm the fatigue life of solder ball joints. In addition, the mechanical fatigue tests using three-point bending method were carried out and compared with the thermal fatigue tests. On the other hand, equivalent inelastic strain range was estimated by stress-strain analysis of finite element method. The equation of fatigue life evaluation of $\mathrm{Al}$ Base BGA solder ball joints was determined using Coffin-Manson's law.

Key Words: Ball Grid Array Package, Al, Bending, Solder Joint, Reliability, Fatigue

\section{1. はじめに}

電子機器の小型軽量化，高性能化に伴い，半導体パッケ ージの多ピン化が進み, BGA(Ball Grid Array)の使用が増 えつつある。また，LSIチップの消費電力は増大する傾向 にあり，その放熱性も重要視されている。

この流れから，金属をべースプレートとして利用したメ タルベースBGAが注目されている。特に金属にAl（アル ミニウム）を採用したAlベースBGAは，Al板とサブスト レート（プリント配線板 ; ガラスエポキシ基材FR4）を貼 り合わせた単純構造のBGAであり，高放熱で軽量という 特徴を有している（Fig. 1)。

Alは非常に軽量で熱伝導性に優れ，安価な材料だが，Si やFR4と比較して熱膨張率が大きい（Table 1)。そのため, Alをメタルベースに採用した本構造では, 熱負荷が加わ った場合に，Alベースとサブストレートの接着部に熱的

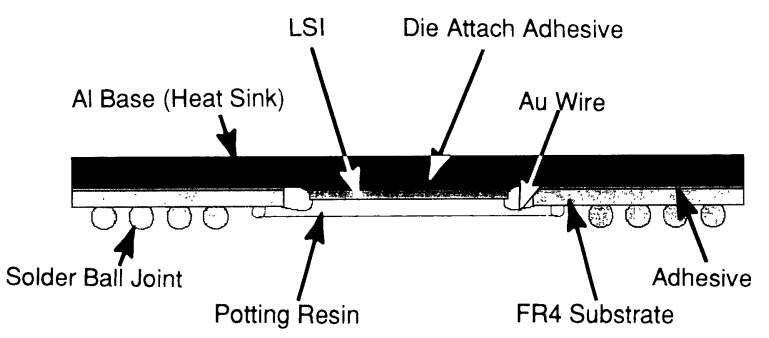

Fig.1 Structure of AI-Base BGA
不整合が発生するとともに，それに起因する反り変形が BGA自体に生じる。よって疲労強度，応力緩和性などに 関して十分な信頼性評価を実施する必要がある。

さらにマザーボードに実装された後に温度サイクルのよ うな繰り返し熱負荷を受けると, 上記反り変形により BGAとマザーボード間のはんだボール接合部，特に変形 量の大きいBGA外周の接合部に応力が集中する。その結 果, はんだボールのクラック，さらにはボール破断による 導通不良が発生する。よって, AlベースBGAの挙動を把 握し，はんだ接合部の疲労寿命評価方法を確立することは 重要な課題である。

そこで，著者らはまずマザーボードへ実装したAlベー スBGAに関して熱疲労試験を実施し，はんだボール接合 部の疲労寿命を確認した。次に, 疲労試験時間の短縮化と

Table 1. Material Properties

\begin{tabular}{c|c|c|c}
\hline Material & $\begin{array}{l}\text { Thermal } \\
\text { Coef. } \\
(\mathrm{ppm} / \mathrm{K})\end{array}$ & $\begin{array}{c}\text { Thermal } \\
\text { Conduct. } \\
(\mathrm{W} / \mathrm{m} \cdot \mathrm{K})\end{array}$ & $\begin{array}{c}\text { Density } \\
\left(\mathrm{g} / \mathrm{cm}^{2}\right)\end{array}$ \\
\hline $\mathrm{Al}$ & $21 \sim 23$ & 240 & 2.7 \\
\hline $\mathrm{Cu}$ & 16 & 390 & 8.9 \\
\hline $\mathrm{Kovar}$ & 4.4 & 17 & 8.3 \\
\hline $\mathrm{Al}_{2} \mathrm{O}_{3}$ & 7 & 20 & 3.8 \\
\hline $\mathrm{FR} 4$ & $14 \sim 16$ & 0.2 & 1.6 \\
\hline $\mathrm{Si}$ & 3.5 & 150 & 2.3 \\
\hline
\end{tabular}


して機械的疲労試験を 3 点曲げ方式にて実施し，熱疲労試 験との整合性を調査した。さらに，設計段階においてはん だボール接合部の疲労寿命予測を可能にするために, 疲労 試験によって得られる疲労寿命と, FEM(Finite Element Method)による応力ひずみ解析によって得られるひずみ振 幅の関係を調べ，AlベースBGAの疲労寿命評価則を導い た。

\section{2. 熱疲労試験}

試験片はFig. 1 に示した構造のAlベースBGAで，外形サ イズ $25 ， 27 ， 30 ， 35 ， 38 \mathrm{~mm}$ 角を用意した。はんだボール 接合部数は外形サイズ $27 \mathrm{~mm}$ 角の場合で 256 ピン, $38 \mathrm{~mm}$ 角 の場合で552ピンになる。パッケージ厚さはすべてAlベー スが $0.5 \mathrm{~mm}$ ，サブストレート $0.5 \mathrm{~mm}$ である。また，はんだ ボールランド径は $\phi 0.55 \mathrm{~mm} て ゙, \phi 0.70 \mathrm{~mm}$ の Sn $63 \mathrm{~Pb} 37$ 共晶 はんだボールによりリフローによってバンプを形成した。

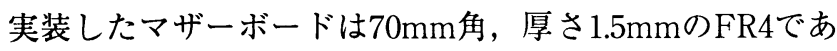
り，パッケージの実装高さは $1.5 \mathrm{~mm}$ 程度になる。なお，ワ イヤボンディングパッド部ですべてのはんだボール接合部 を短絡させている。

試験条件をTable 2 に示す。 3 条件の温度レンジを設定 し, 保持時間, 昇降温時間は一定とした。不良判定は, は んだ接合部が破断し導通がオープンになった場合, および 配線パターンを含めたはんだボール接合部間の抵抗值変化 率が10\%以上になった時点とし, 不良が確認されなかった 最終サイクルをBGAの寿命とした。また, 目標とした疲 労寿命サイクル数は, BGAの搭載機器や使用環境によっ ても異なるが，ここでは500cycleとして寿命評価を行った。

Fig. 2 に外形サイズ $27 \mathrm{~mm}$ 角と $38 \mathrm{~mm}$ 角のAlベースBGA の熱疲労試験結果をワイブルプロットしたものを示す。 $27 \mathrm{~mm}$ 角BGAでは, 最も撖しい試験条件Aでも断線開始が $1000 \mathrm{cycle}$ ，一般的に寿命の評価基準として多用されてい る0.1\%不良時で700cycle程度であり, 実用レベルの信頼性 があることを確認できた。また，断線は全試験片が外周コ 一ナ部（四隅）のはんだボール破断であり, 他の接合部で 断線不良が生じることはなかった。

また，38mm角BGAは最も厳しい試験条件 Aで500cycle から断線が発生し， $0.1 \%$ 不良時寿命は約350cycleである。 目標サイクルを達成するには構造の再検討, 部材の変更な どが必要であることがわかった。これに関しては 5 章で詳 述する。

Table 2. Thermal Fatigue Test Conditions

\begin{tabular}{c|r|c|c|c}
\hline & $\begin{array}{c}\text { Max./Min. } \\
\text { Temp. }\left({ }^{\circ} \mathrm{C}\right)\end{array}$ & $\begin{array}{l}\text { Range of } \\
\text { Temp. }\left({ }^{\circ} \mathrm{C}\right)\end{array}$ & $\begin{array}{l}\text { Holding } \\
\text { Time (min) }\end{array}$ & $\begin{array}{l}\text { Rise/Fall } \\
\text { Time(min) }\end{array}$ \\
\hline A & $125 /-40$ & 165 & & \\
\cline { 1 - 2 } B & $100 /-40$ & 140 & \multirow{2}{*}{15} & \multirow{2}{*}{3} \\
\cline { 1 - 3 } C & $90 /-25$ & 115 & & \\
\hline
\end{tabular}

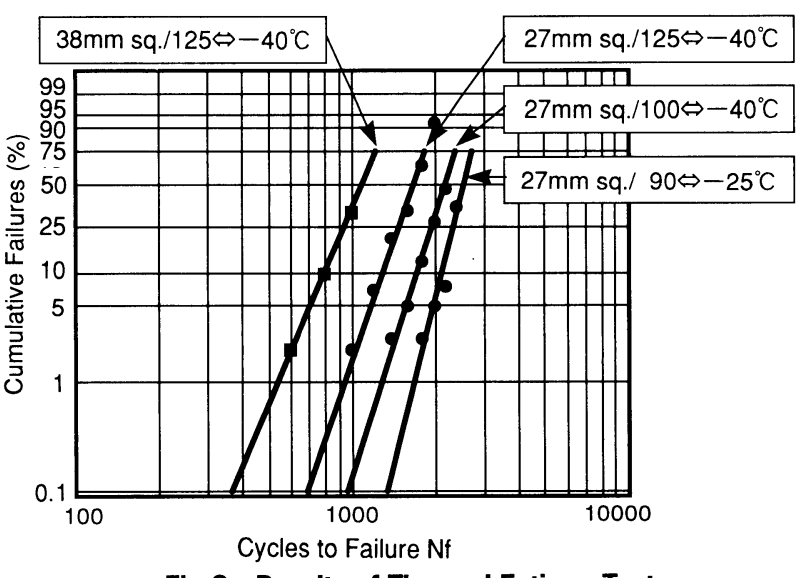

Fig.2 Results of Thermal Fatigue Test

\section{3. 機械的疲労試験}

熱疲労試験は $500 \mathrm{cycle}$ で約 $300 \mathrm{Hr}$ もの長時間を必要と することから，試験時間の短縮を図るため機械的疲労試験 を実施した。これまでの研究により，はんだ材の材料特性 および温度依存性，ひずみ速度の影響などを考慮してはん だ接合部の非線形ひずみ振幅を評価することができれば, BGAのはんだボール接合部やリード型はんだ接合部など の熱疲労試験による疲労寿命評価は, 機械的疲労試験で代 用可能であるとの結論が得られている"2》。ただし，剪断 変形と併せて反り変形を含めた方法での機械的疲労試験に ついては確立されたデー夕報告がなされていない。そこで 著者らはA1ベースBGAの反り変形を考慮するために 3 点 曲げ方式で機械的疲労試験を行い, 熱疲労試験との整合性 を確認することにした。

著者らが実施した 3 点曲げ方式の機械的疲労試験の利点 のひとつは剪断変位を与える試験と比較して, 振幅を大き くとれることである。剪断変位入力の機械的疲労試験の場

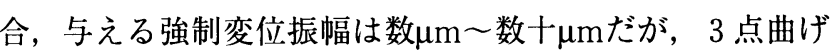
方式では $100 \mu \mathrm{m}$ 以上の大きな変位を与えることが可能であ る。このため, クラック発生の観察が容易になり, 試験機 の変位制御にも余裕ができるため試験デー夕の信頼性が向 上する。

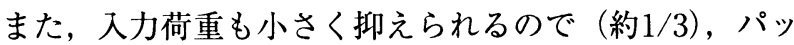
ケージを小さく切り出したり, はんだボール接合部数を減 らすなどの加工をBGAに施すことなくパッケージ全体で 評価することができる。よって試験が単純化され, 試験準 備時間を短縮することが可能になり, 試験データの信頼性 も向上させることができる。

3 点曲げ方式の機械的疲労試験方法の概略をFig. 3 に示 す。マザーボード両端部を固定し, パッケージ中心裏面か ら $0.2 \mathrm{~Hz}$ の三角波で一定の強制変位を与えた。固定両端間

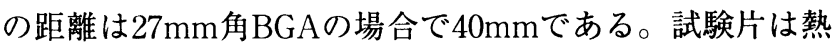
疲労試験の場合と同様であるが, 実装するマザーボードの 側面 2 辺は，はんだ接合部を観察を容易にするために BGAと同じサイズまで切断した。不良判定はマイクロス 

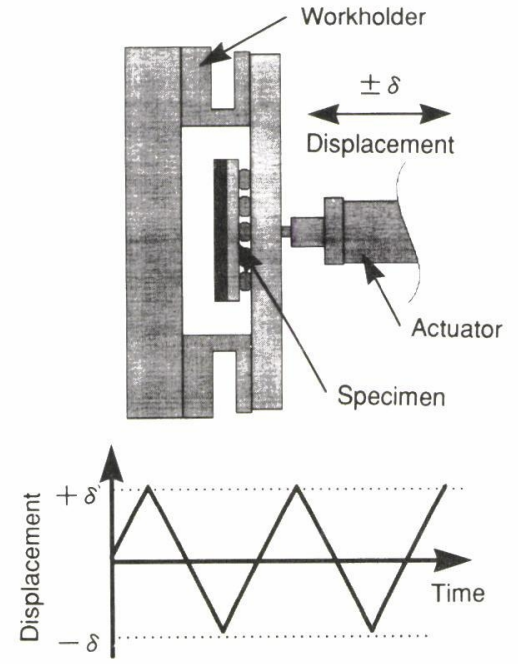

Fig.3 Three-Point Bending Mechanical Fatigue Test

コープではんだ接合部を観察し，発生したクラックの長さ

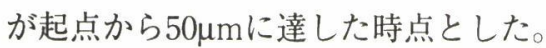

試験では与える強制変位を変化させて，100cycle程度の 短寿命から10000 cycle程度の長寿命まで幅広くデー夕を求 めた。 $27 \mathrm{~mm}$ 角BGAの疲労試験結果として，与えた強制変 位（全振幅）とそのときの疲労破壊サイクル数をTable 3 に，はんだボール接合部および発生したクラックの拡大写 真をFig. 4 に示す。クラックがボール接合部端部から発生 し，はんだ内部へ成長しているのがわかる。

Table 3. Results of Mechanical Fatigue Test

\begin{tabular}{c|c}
\hline $2 \delta(\mu \mathrm{m})$ & Nf \\
\hline 100 & 9000 \\
\hline 110 & 3400 \\
\hline 115 & 2400 \\
\hline 118 & 1300 \\
\hline 120 & 850 \\
\hline 130 & 700 \\
\hline 150 & 270 \\
\hline 200 & 230 \\
\hline
\end{tabular}

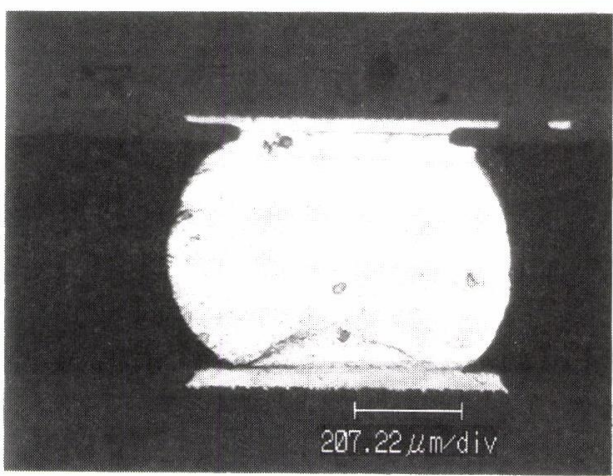

\section{FEM解析}

熱疲労試験および機械的疲労試験に対応する形でFEM による応力ひずみ解析を行った。Fig. 5 に解析モデル概略 を示す。FEM解析コードABAQUSおよびMARCを用いて 2 次元平面ひずみ要素を使用し, 弾塑性クリープ解析を実 施した（なお機械的瘦労試験に関しては弾塑性挙動のみを 考虑している)。入力した物性をTable 4 に示す。はんだ 材は融点が低いため，クリープの影響を無視できない。そ こではんだの材料特性としてクリープ特性を次式の Norton則の形で考慮した。

$$
\varepsilon_{\mathrm{c}}=\mathrm{A} \cdot \sigma^{\mathrm{n}}
$$

ただし， $\varepsilon_{\mathrm{c}}$ は相当クリープひずみ速度， $\sigma は$ Misesの相当 応力である。クリープ定数 $\mathrm{A}$ とクリープ硬化指数nに関し ては, 向井らの報告 ${ }^{3} に よ り$ 温度依存性があることがわか っている。また，降伏応力の温度依存性に関して，次式の ような結果が報告されており"，クリープ特性と同様に考 慮した。

$$
\sigma_{Y}(\mathrm{~T})=101.6-0.227 \times \mathrm{T}[\mathrm{K}] \mathrm{MPa}
$$

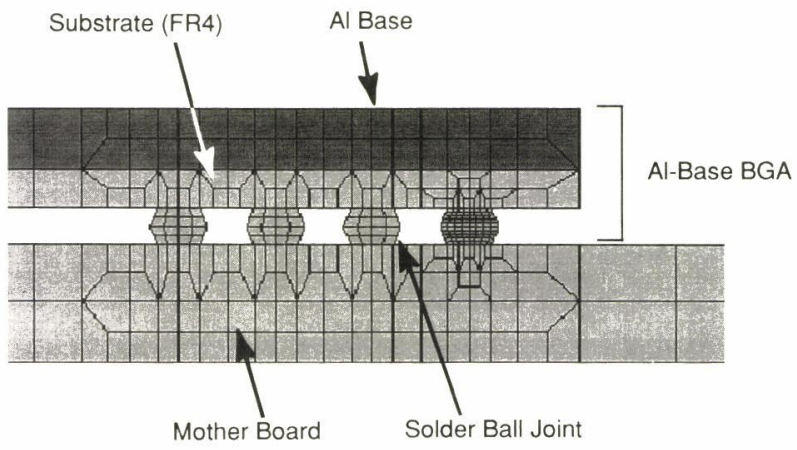

Fig.5 FEM Model of AI-Base BGA

Table 4. Material Properties

\begin{tabular}{c|c|c|c}
\hline Material & $\begin{array}{l}\text { Young's } \\
\text { Modulus } \\
(\mathrm{GPa})\end{array}$ & $\begin{array}{l}\text { Poisson's } \\
\text { Ratio }\end{array}$ & $\begin{array}{l}\text { Thermal } \\
\text { Coef. } \\
\text { (ppm/K) }\end{array}$ \\
\hline $\mathrm{Al}$ & 73.5 & 0.345 & 23.0 \\
\hline Sn63Pb37 & 20.0 & 0.388 & 24.7 \\
\hline FR4 & 11.0 & 0.150 & 15.0 \\
\hline
\end{tabular}

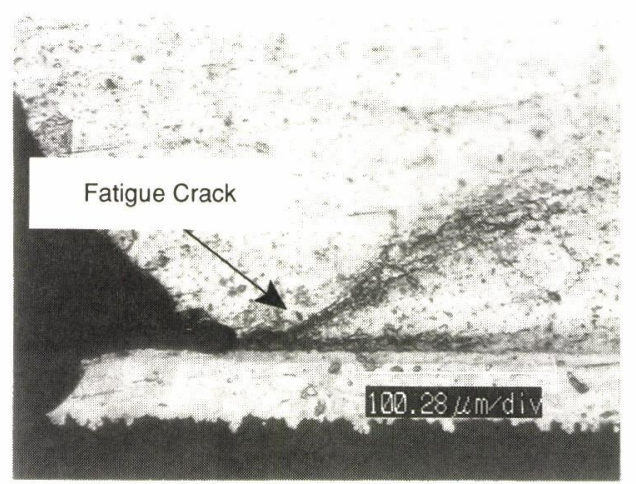

Fig.4 Cross Section Views of Solder Ball Joint after Mechanical Fatigue Test 


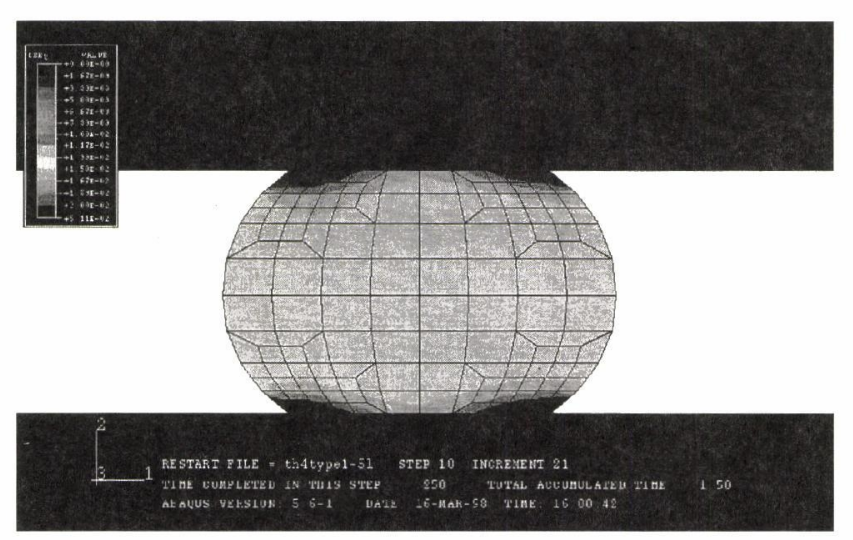

Total Equivalent Creep Strain

Fig.6 Result of FEM Analysis of Solder Ball Joint

解析は 5 cycle程度行い， 1 cycle当たりに生じるはんだ ボール接合部の相当非線形ひずみ振幅を求めた。最も応力 集中のあったはんだボール接合部の相当非線形ひずみの分 布をFig. 6 に示す。機械的疲労試験において観察されたク ラック発生位置と応力集中位置は一致していることから， ひずみ評価を応力集中部からはんだ内部 $50 \mu \mathrm{m} の$ 位置で行 うことにした。

次に, 熱疲労試験および機械的疲労試験の相当非線形ひ ずみの履歴の比較をFig. 7 , Fig. 8 に示す。熱疲労試験の 履歴は $27 \mathrm{~mm}$ 角BGAで試験条件 $\mathrm{A}\left(-40^{\circ} \mathrm{C} / 15 \mathrm{~min} \Leftrightarrow 125^{\circ} \mathrm{C}\right.$ /15min）の熱負荷を加えた場合, 機械的疲労試験の履歴 は強制変位 $200 \mu \mathrm{m}$ 与えた場合のものである。両試験とも剪 断（xy）方向成分に加えて, 反り（yy）方向成分のひず みも生じており, 反り変形の影響が大きいことがうかがえ る。3 点曲げ方式の機械的疲労試験では, 剪断変形のみを

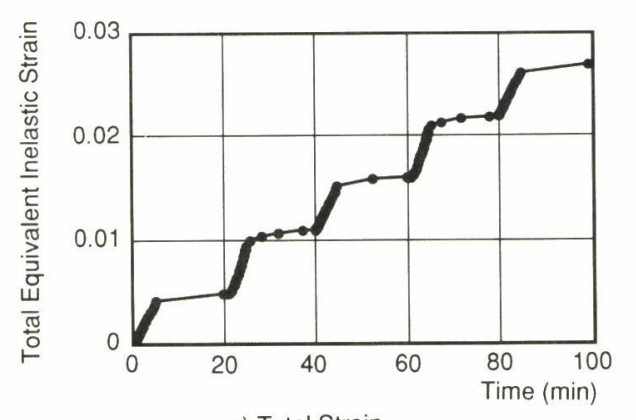

a) Total Strain

Fig.7 Hysteresis of Equivalent Inelastic Strain in Thermal Fatigue Test

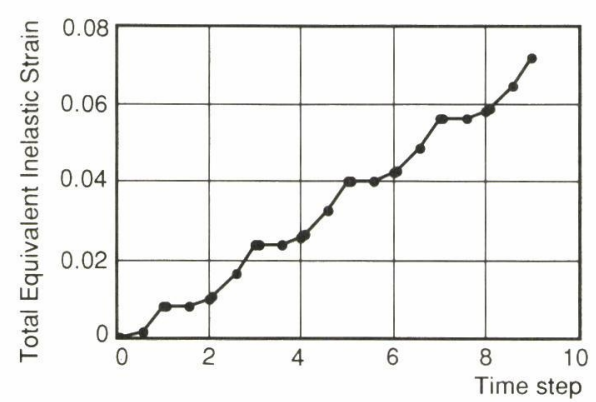

a) Total Strain

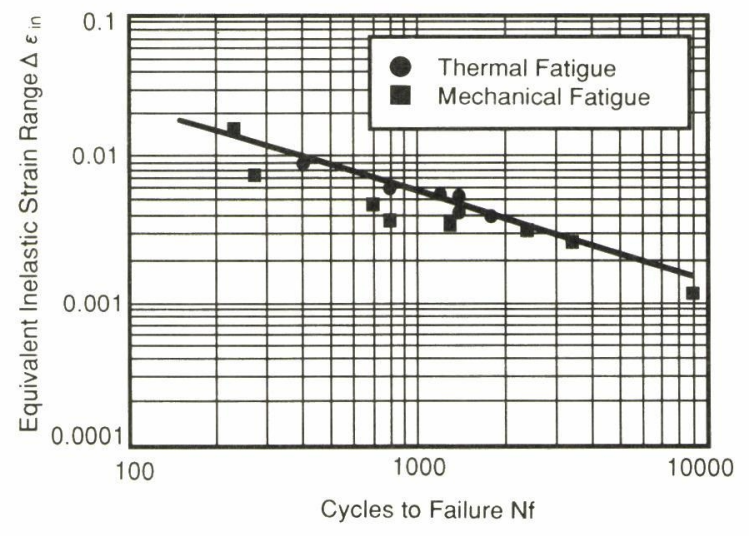

Fig.9 Relation between $\Delta \varepsilon_{\text {in }}$ and Nf

与える場合では発生しないyy方向成分のひずみを発生さ せることが可能であり，Al゙ーースBGAのように反り変形 の挙動を示す場合には有効であることがわかった。

\section{5. 疲労寿命評価}

Fig. 9 に, 熱疲労試験と機械的疲労試験から得られた疲 労寿命結果NfとFEMによる応力ひずみ解析によって得ら れた相当非線形ひずみ振幅 $\Delta \varepsilon_{\text {in }}$ の関係を示す。両者は直線 関係にあり, 図で示すように最小二乗法で直線近似するこ とができる(ただし直線は熱疲労試験デー夕のみで作成)。

すなわち, 繰り返し反り変形を受けるAlベースBGAの はんだボール接合部の疲労強度は, 相当非線形ひずみ振幅 に基づいて整理することでCoffin-Manson則りによって評価 することが可能であるといえる。よってAlベースBGAの はんだボール接合部の疲労寿命評価則は次式によって表す ことができる。

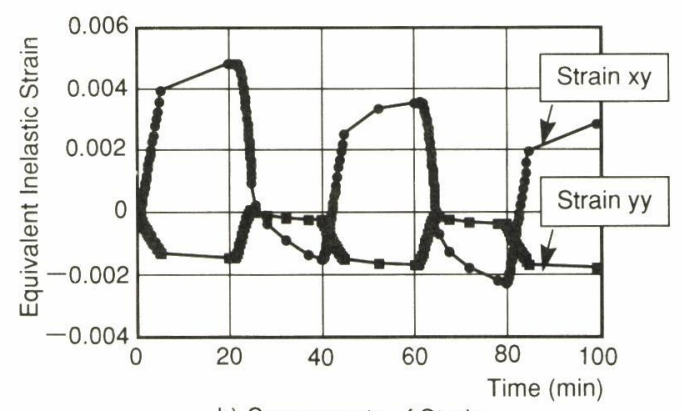

b) Components of Strain

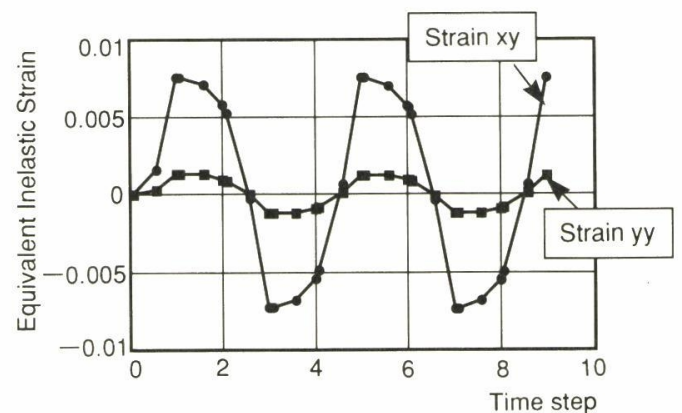

b) Components of Strain

Fig. 8 Hysteresis of Equivalent Inelastic Strain in Mechanical Fatigue Test 
$\mathrm{Nf}=0.173 \Delta \varepsilon_{\text {in }}{ }^{-1.687}$

パッケージの材料物性を正確に把握し, 応力ひずみ解析 を行って相当非線形ひずみ振幅 $\Delta \varepsilon_{\text {in }}$ を求めることができれ ば，上式により AlベースBGAの疲労寿命 Nfを設計段階で 予測することが可能になる。

また, 機械的疲労試験の結果もほほ熱疲労試験結果と一 致しており，加速試験として有効と判断できる。応力ひず み解析結果では熱疲労試験と機械的疲労試験において, ひ ずみのxy成分と $\mathrm{yy}$ 成分の比率は正確には一致していない。 しかし，相当ひずみの考え方を用いCoffin-Manson則を適 用して評価可能であることが明らかになったため，ひずみ 成分の比率を議論することなく, 外周部に応力集中が生じ るはんだ接合部の評価に， 3 点曲げ式の機械的疲労試験を 適用できると考えられる。

さて前述したように，38mm角BGAの試験条件Aにおけ る熱疲労寿命Nfは疲労寿命目標の500cycleに到達していな かった。そこで, 応力ひずみ解析を行い, 疲労寿命評価則 を参考に構造の再検討を行った。パッケージ部材の材質, サブストレートの設計変更をしない条件でFEM解析を行 ったところ， Alベースの外形サイズのみを $38 \mathrm{~mm}$ 角から $30 \mathrm{~mm}$ 角に縮小することで $\Delta \varepsilon_{\text {in }}$ が 0.006 になり, 疲労寿命評 価則からNfはおよそ1000cycleと推定できた。

実際に試験片を作成して熱疲労試験を実施し疲労寿命の 確認を行った。その結果のワイブルプロットをFig.10に示 す。疲労寿命は大幅に向上し， $0.1 \%$ 不良時で約 1100 cycle の疲労寿命であった。疲労寿命評価則から推定される寿命 とほほ一致する結果を得ることができ, 設計段階での疲労 寿命予測が可能であることを確認できた。

\section{6. まとめ}

AlベースBGAのはんだボール接合部について，熱疲労 試験, 機械的疲労試験および, FEMによる応力ひずみ解 析を行って疲労寿命を評価した。

1) AlベースBGA のように熱変位が大きく，反り変形 の挙動を示す構造でも十分な実装信頼性が得られるこ とを確認できた。

2) 応力ひずみ解析から得られる相当非線形ひずみ振幅 を用いて疲労強度を評価することで，Alベース BGA のはんだボール接合部はCoffin-Manson則に従い疲労 寿命評価が可能である。

3）AlベースBGAのはんだボール接合部の疲労寿命評 価則を求め, 設計段階での疲労寿命予測が可能である

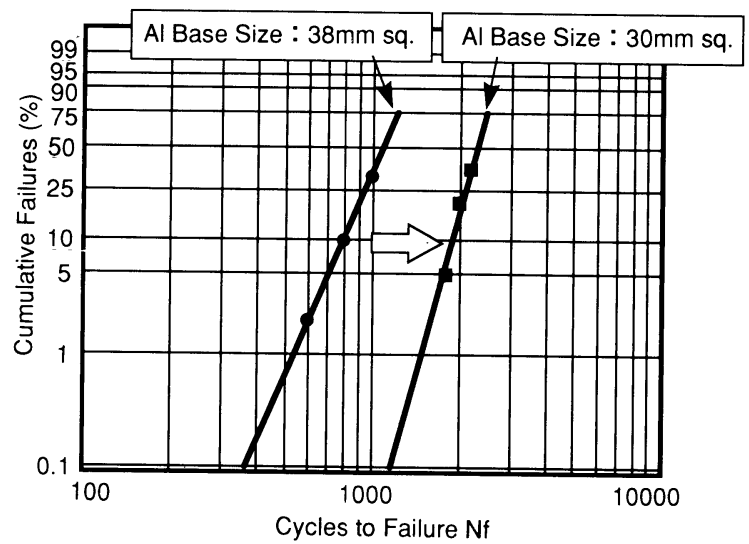

Fig.10 Results of Thermal Fatigue Test

ことを確認した。

4) AlベースBGAの 3 点曲げ式の機械的疲労試験の結 果は, 熱疲労試験の結果とほほ一致する。反り変形を 有するパッケージのはんだボール接合部の疲労強度評 価には有効である（試験時間は約 $1 / 100 に$ 短縮）。

本論文では，AlベースBGAのはんだボール接合部の疲 労寿命への, 外形サイズの影響を調べたが，はんだボール 接合部形状やべース材や接着層の板厚・材質などを変更し た場合の効果を捉えていない。今後は以上を考虑して試験 片数を増やし, 疲労寿命評価則の信頼性の向上に努めたい。 （1998.7.23-受理１998.9.24-再受理）

\section{文献}

1) 于 強, 白鳥正樹 : “表面実装はんだ接合部の強度信頼性評 価”, 回路実装学会誌, Vol.12, No.6, pp.384-390 (1997).

2) 于 強, 白鳥正樹: “マイクロエレクトロニクスパッケージ はんだ接合部のクリープ／低サイクル疲労強度評価”, 日本 機械学会研究協力部会RC-128「電子デバイス／電子機器の 強度信頼性評価に関する研究分科会」報告書, pp. $245-340$ (1996).

3) 向井 稔, 他: “ICパッケージ半田接合部の弾クリープ解析 と疲労寿命”, 日本機械学会 [No.910-79], 第 4 回計算力学 講演論文集, pp.223-224 (1991).

4) T.Y.Pan : "Thermal Cycling Induced Plastic Deformation in Solder Joints-Part 1: Accumulated Deformation in Surface Mount Joints", ASME Journal of Electronic Packaging, Vol.113, pp.8-15 (1991).

5) S.S.Manson: "Interfaces between Fatigue, Creep, and Fracture", International Journal of Fracture Mechanics, Vol.2, No.1, pp.327-363 (1966). 